\title{
ТРЕНІНГОВА ПРОГРАМА ГАРМОНІЗАЦІЇ ПОЧУТТЯ ВЛАСНОСТІ
}

\section{Губеладзе Ірина}

Інститут соціальної та політичної психології НАПН України,

м. Київ, Україна

irynagubeladze@gmail.com

ORCID 0000-0001-8023-6408

Mema. Метою статті $є$ розроблення змісту і структури та презентація авторської програми гармонізації почуття власності особи.

Meтоди. Для розробки тренінгової програми було використано низку методів інтерактивної роботи і психоедукації з метою гармонізації почуття власності: метод незавершених речень, рольова гра, симуляція, мозковий штурм, групові методи роботи, дискусія, психологічні практикуми, творчі домашні завдання тощо.

Результати. У статті представлено авторську тренінгову програму гармонізації почуття власності, яка складається зі вступу, завершальної частини та трьох основних модулів: «Почуття власності як соціально-психологічний феномен: моє, наше, чуже, нічиє», «Чинники посилення почуття власності: контроль, самоінвестування та інтимне знання», «Наслідки і можливості гармонізації почуття власності». Кожен з модулів має на меті опрацювання різних складових почуття власності: контроль, самоінвестування грошей, часу чи інших ресурсів та глибоке інтимне знання.. Загальний обсяг тренінгової програми складає 26 академічних годин. Запропонована тренінгова програма може бути використана для гармонізації почуття власності особи, як серед старшокласників і студентів, так і серед дорослого населення загалом.

Висновки. Впровадження та вивчення ефективності тренінгової програми гармонізації почуття власності показало доцільність ії використання серед старшокласників та студентської молоді, а також дорослого населення, що сприяло оптимізації прояву відповідальності, самоефективності, самоідентичності та залученості особи.

Перспективи подальших досліджень вбачаємо в розробці програми психологічного тренінгу для гармонізації почуття власності щодо територіальної громади та власної країни.

Ключові слова: почуття власності, психологічна власність, гармонізація почуття власності, тренінгова програма, психоедукація

(C) Губеладзе I., 2021. Ця стаття відкритого доступу на умовах CC BY-NC 4.0 


\section{Iryna Hubeladze. Training Program for Sense of Ownership Harmonization.}

Purpose. The purpose of the article is to develop the content and structure and presentation as well of the author's training program to harmonize the sense of ownership of the person.

Methods. A number of methods for interactive work and psychoeducation were used to develop the training program in order to the sense of ownership harmonize: the method of incomplete sentences, role play, simulation, brainstorming, group work, discussion, psychological workshops, creative homework and more.

Results. The article presents the author's training program to harmonize the sense of ownership, which consists of an introduction, final part and three main modules: "Sense of ownership as a socio-psychological phenomenon: mine, ours, someone else's, nobody's", "Factors of strengthening the sense of ownership: control, self-investment and intimate knowledge"," Consequences and opportunities for sense of ownership harmonization". Each of the modules aims to develop different components of a sense of ownership: control, self-investment of money, time or other resources and deep intimate knowledge. The total amount of the training program is 26 academic hours. The proposed training program can be used to harmonize the sense of ownership, both among high school and university students, and among the adult population in general.

Conclusions. The introduction and study of the effectiveness of the training program to harmonize the sense of ownership showed the feasibility of its use among high school and student youth, as well as adults, which helped to optimize responsibility, self-efficacy, self-identity and involvement. The prospects for further research are in the development of a psychological training program to harmonize the sense of ownership of the local community and own country.

Keywords: sense of ownership, psychological property, harmonization of sense of ownership, training program, psychoeducation

\section{Губеладзе Ирина. Тренинговая программа гармонизации чувства собственности.}

Цель статьи - разработать содержание, структуру и изложение авторской обучающей программы для гармонизации чувства собственности человека.

Memoды. Для разработки программы обучения с целью гармонизации чувства собственности использовался ряд методов интерактивной работы и психоэдукации: метод незаконченных предложений, ролевые игры, симуляция, мозговой штурм, групповая работа, обсуждение, психологические семинары, творческое домашнее задание и т.д.

Peзультаты. В статье представлена авторская программа обучения гармонизации чувства собственности, которая состоит из введения, заключительной части и трех основных модулей: «Чувство собственности как социально-психологический феномен: мое, наше, чужое, ничье», «Факторы усиления чувства собственности: контроль, самоинвестирование и глубокое сокровенное знание», «Последствия и возможности для гармонизации чувства 
собственности». Каждый из модулей направлен на развитие различных компонентов чувства собственности: контроля, самостоятельного вложения денег, времени или других ресурсов и глубоких сокровенных знаний. Общий объем учебной программы составляет 26 академических часов. Предлагаемая программа обучения может быть использована для гармонизации чувства собственности как среди старшеклассников и студентов вузов, так и среди взрослого населения в целом.

Bықоды. Внедрение и изучение эффективности программы обучения по гармонизации чувства собственностии показало целесообразность ее использования среди старшеклассников и студенческой молодежи, а также среди взрослых, что помогло оптимизировать ответственность, самоэффективность, самоидентификацию и вовлеченность. Перспективы дальнейших исследований заключаются в разработке программы психологического тренинга для гармонизации чувства сопричастности к местному сообществу и своей стране.

Ключевые слова: чувство собственности, психологическая собственность, гармонизация чувства собственности, программа обучения, психообразование.

Вступ. Нівелювання і знецінення потреби у власності протягом тривалого періоду призвело до ослаблення почуття власності і не сформованості економічного мислення сучасних українців та їхньої суб’єктної позиції власника як щодо свого життя, соціальних стосунків, так і щодо колективної власності. Як стверджують дослідники, власність - системотвірний чинник становлення як ідентичності особи, так і особливостей іiі взаємодії 3 іншими та відчуття власної успішності і спроможності (Бурменко, Карнышев, 2003; Пайпс, 2008; Хазратова. 2009; Beaglehole, 2015; Noguti \& Bokeyar, 2014; Jussila, Tarkiainen, Sarstedt \&Hair, 2015; Poretski, Arazy, Lanin \& Nov, 2021).

Як продовження теорії психологічної власності (Pierce, Kostova \& Dirks, 2002), ми розглядаємо почуття власності як суб'єктивне емоційне переживання людини щодо належності їй певних об'єктів власності, що відображає зміст та значення, яке мають для неї реальні або абстрактні, конкретні або узагальнені об'єкти власності, тобто все те, що може назвати своїм (Губеладзе, 2020). Як стверджував У. Джеймс, втрата майна, яке людина відчуває своїм і яке поступово стає частиною іiі самості, iï «Я», може викликати у людини відчуття зменшення, звуження іiі особистості». Накопичення матеріальних активів також може бути пов'язане 3 більш низькою самооцінкою: 
чим вона нижча, тим вище бажання компенсації у вигляді накопичення власності (Джеймс, 1991). Почуття власності не тільки підвищує цінність майна для свого власника, воно також підсилює готовність людини піклуватися про те, що вона вважає «своїм», та інвестувати гроші, зусилля і час у «своє» майно (Kahneman, Knetsch \& Thaler, 1991).

Дослідження підтверджують, що зосередженість на володінні та придбанні може призвести до конфлікту між особистими й колективними цінностями. Занадто сильне власницьке почуття може перешкоджати співробітництву, оскільки люди прагнуть передусім зберігати контроль за своєю власністю (Pierce, Kostova \& Dirks, 2002; Preston\&Gelman, 2020). Негативні прояви почуття власності можуть виявлятися і щодо різних сфер реалізації особи як власника, зокрема й у політиці. Як стверджує Дж. Пірс, в процесі переходу від авторитарного режиму до демократичного лідери, відчуваючи країну своєю власністю, будуть чинити опір передачі влади і впровадження демократичних інститутів.

3 одного боку, почуття власності має посилювати конкуренцію i боротьбу за «своє», а 3 іншого, як показують результати досліджень, може, навпаки, активізувати альтруїзм і готовність допомагати іншим (Poretski, Arazy, Lanin \&Nov, 2021). Оскільки відчуття власності підсилює відчуття відповідальності за «своє» майно, воно може сприяти збереженню суспільних благ - наприклад, навколишнього середовища. У такий спосіб можна попереджувати «трагедії громад», коли загальний доступ до ресурсу виснажує його або знищує. До такого висновку прийшли дослідники Дж. Пек та С. Шу. Їхні експерименти показали, що почуття власності мотивує «власників» суспільного блага, наприклад озера або парку, берегти і захищати його (Peck \& Shu, 2018).

Почуття власності може мати різні конотації і проявлятися порізному. Як писав У. Джеймс, усі об'єкти власності людини однаково викликають у неї емоції: якщо власність збільшується і процвітає почуття власності торжествує, якщо ж власність виснажується i зменшується - людина може відчувати зневіру i розпач (Джеймс, 1991). Додамо тільки, що насправді негативні переживання можуть бути пов’язані як із браком певного об’єкта власності, так i 3 посиленим його проявом, яке викликає надмірну тривогу, страх втрати i фрустрацію. Для відпрацювання таких негативних емоцій 
важливо усвідомлювати свої стосунки 3 конкретним об'єктом власності. 3 огляду на це постає потреба розробки практичних технік і програм супроводу, спрямованих на гармонізацію почуття власності особи.

Щодо практичних розробок у цьому напрямі, то існують деякі програми щодо розвитку монетарної культури старшокласників (Зубіашвілі, 2018), формування адекватного ставлення до грошей студентів (Карамушка \& Ходакевич, 2017). Проте гостро бракує програм з гармонізації прояву саме почуття власності, взагалі формування адекватного ставлення до власності. Отже соціальна значущість проблеми та іï недостатня розробленість визначили актуальність і мету нашого дослідження.

Мета статті - розробити зміст і структуру та презентувати авторську тренінгову програму гармонізації почуття власності особи.

Для досягнення поставленої мети було визначено низку завдань:

-здійснити теоретичний аналіз наявних сучасних емпіричних та практичних розробок щодо вивчення, активізації та гармонізації почуття власності;

- розробити тренінгову програму гармонізації почуття власності;

- перевірити ефективність запропонованої програми.

Відзначимо тільки, що в цій публікації ми зосередилися тільки на викладі структури і змісту програми.

Методи та процедура дослідження. Тренінгова програма - один із запропонованих методів для практичної психологічної роботи 3 темою власності. Побудову структури і змісту тренінгової програми здійснено на основі загальних принципів групової роботи.

В основу розробки тренінгової програми покладено положення теорії психологічної власності Дж. Пірса, який стверджував, що чинниками активізації чи мотивами психологічного привласнення $є$ контроль, самоінвестування та грунтовні інтимні знання. Посилення почуття власності відповідно призводить до підвищення рівня прояву його окремих показників: самоефективності, самоідентичності, відчуття належності та відповідальності (Pierce, Kostova \& Dirks, 2002). Ми виходимо $з$ положення, що почуття власності може мати як позитивну, так і негативну конотацію.

Розробка тренінгової програми відбувається на основі наявних теоретично-методологічних основ вивчення психологічної власності і почуття власності та з урахуванням наявних практичних розробок у 
цьому напрямі. А також на основі результатів емпіричних досліджень автора, які відображені у попередніх публікаціях (Губеладзе, 2020).

Переваги тренінгової форми роботи пов'язані передовсім 3 основними принципами групової роботи. Активні форми роботи дають змогу активізувати внутрішню мотивацію учасників і з опорою на їхні індивідуальні потреби та інтереси залучити їх до ефективної спільної роботи. Високий рівень рефлективності вправ дозволяє інтеріоризувати отриманий досвід $\mathrm{i}$ «привласнити» його. Проблемність самих завдань, робота 3 актуальними, важливими питаннями і відповідно переживаннями учасників, які не мають і не можуть мати єдиного правильного рішення. Активна творча взаємодія учасників забезпечує креативність та командність у роботі і пошуку спільних рішень, а також занурення та використання колективного досвіду проживання почуття власності.

Мета тренінгової програми - формування гармонійного переживання почуття власності у різних його сферах прояву.

Завдання тренінгу:

- оволодіння знаннями про сутність почуття власності як соціально-психологічного феномену, чинники та особливості його прояву;

- оволодіння навичками рефлексії щодо актуального стану переживання почуття власності;

- визначення ефективних стратегій долання негативних проявів почуття власності і пов'язаних 3 цим переживань.

Частина запропонованих у програмі вправ і технік $\epsilon$ авторською розробкою, а частина - модифікацією загальновідомих технік і прийомів. Проте змістове наповнення кожної 3 вправ $\epsilon$ повністю авторською і відповідає меті і завданням тренінгу.

Для перевірки ефективності запропонованої програми використали два види опитування: 1) кількісне опитування 3 кількісними показниками, зокрема суб'єктивними оцінками рівню контролю, самоінвестування часу і ресурсів та глибини знань про об'єкт власності, а також показників суб'єктивного відчуття власності; 2) відповіді на відкриті питання щодо ефективності самого тренінгу та суб'єктивної оцінки відчутних змін.

Загальна структура тренінгової програми 
Таблиия 1

Структура та обсяг тренінгової програми гармонізації почуття власності

\begin{tabular}{|l|l|l|}
\hline \multirow{2}{*}{$№$} & \multicolumn{1}{|c|}{ Тема модулю } & $\begin{array}{l}\text { Кількість } \\
\text { годин }\end{array}$ \\
\hline 1 & Вступ & 2 \\
\hline 2 & $\begin{array}{l}\text { Модуль 1. «Почуття власності як соціально-психологічний феномен: моє, } \\
\text { наше, чуже, нічиє» }\end{array}$ & 6 \\
\hline 3 & $\begin{array}{l}\text { Модуль 2. «Чинники посилення почуття власності: контроль, } \\
\text { самоінвестування та інтимне знання» }\end{array}$ & 6 \\
\hline 4 & Модуль 3. «Наслідки і можливості гармонізації почуття власності» & 6 \\
\hline 5 & Завершення & 2 \\
\hline 6 & Домашнє завдання & 6 \\
\hline & Усього & 28 \\
\hline
\end{tabular}

\section{Зміст тренінгової програми}

Bcmyn традиційно присвячено знайомству членів групи, уточненню цілей, очікувань учасників та правил роботи групи. На цьому етапі також здійснюється вхідний діагностичний замір.

Модуль 1. "Почуття власності як соціально-психологічний феномен: моє, наше, чуже, нічиє».

Метою цього модулю є рефлексія основних об'єктів та сфер власності, діагностика власного почуття власності та особливостей його прояву.

Завдання 1. Що ви можете назвати словом «моє», «наме», «чуже», «нічиє».

Учасникам пропонують протягом 5-10 хв. методом вільних асоціацій записати відповіді на поставлені питання. Потім обирають 1-3 найбільш значущі об'єкти власності і кожен 3 них оцінюють за 5бальною шкалою, наскільки сильно учасник відчуває суб'єктивне почуття власності щодо цього об'єкта. Тоді учасники об'єднуються в пари і діляться своїми напрацюваннями. Обговорення у спільному колі.

Завдання 2. Мозковий штурм «Що дає людині суб’єктивне відчуття власності».

Учасники у спільному колі пропонують причини, чому у людей 3'являється почуття власності і навіщо воно їм потрібне. Після проведеного мозкового штурму тренер підсумовує і підводить групу до висновків, що:

-почуття власності - універсальний соціально-психологічний феномен, який виникає на основі потреби у власності; 
- воно виникає в усіх людей, але може проявлятися різною мірою щодо різних об'єктів власності і в різні періоди життя;

-проживання почуття власності дає людині відчуття безпеки, контролю, стабільності.

Завдання 3. "Сфери реалізачї почуття власності».

Учасники всліпу обирають аркуші, на яких написані основні сфери реалізації почуття власності (фінансова сфера, територія, матеріальні речі, соціальні контакти, інформаційний простір, тіло, часовий режим, життя в організації, цінності, ідеї, думки, громадянська сфера). Кожна із зазначених сфер трапляється двічі. Після того, як обрали свій листочок, кожен має знайти свою «пару» іншого учасника 3 такою самою сферою. Далі працюють у парі: учасники мають подумати й описати, як проявляється почуття власності саме в цій сфері, які особливості саме такого почуття власності, наскільки часто та інтенсивно проявляться почуття власності в цій сфері, в яких саме соціальних практиках, які загрози втрати можуть бути в цій сфері, i що буде, якщо таке почуття власності буде проявлятися надмірно.

Завдання 4. Індивідуальна робота.

1. Згадайте ситуацію, коли ви відчували надмірне почуття власності щодо того чи того об'єкта. Якими емоціями, переживаннями воно супроводжувалося? До яких дій ви були готові чи як діяли? Наскільки такі переживання і дії були конструктивними i допомагали вам? Якби у вас була можливість щось змінити, що саме ви б змінили і чому?

2. Згадайте ситуацію, коли ви майже не відчували почуття власності щодо певного об'єкта фактичної власності. Якими емоціями й переживаннями це супроводжувалося? До яких дій ви були готові чи як діяли? Наскільки такі переживання і дії були конструктивними і допомагали вам? Якби у вас була можливість щось змінити, що саме ви б змінили і чому?

Обговорення результатів у групі.

Підбиття підсумків

Домашне завдання. Оберіть один об’єкт власності, бажано той, який у вас сьогодні найяскравіше проявився під час першого завдання (можливо, це стосунки 3 якоюсь особою, можливо це ваш час, а можливо це ваша машина...). Протягом наступного тижня: 1) дізнайтесь 5+ нових фактів про цей об’єкт власності, які ви раніше 
ніколи не знали; 2) приділіть цьому об'єкту власності відчутно більше вашого часу та ресурсу (наприклад, машину помити, відвезти на плановий техогляд чи купити килимки; якщо це стосунки, то сплануйте зустріч i проведіть час разом, приготуйте сюрпризподарунок для цієї людини, проявіть свою турботу i т.д.); 3) проконтролюйте певні аспекти щодо об'єкта власності: наприклад, якщо це машина - перевірте, чи все справно працює в машині, чи діє ще страховий поліс; якщо мова про ваш час, то подивіться, чи добре ви його спланували, чи все встигаєте, якщо не встигаєте, то чому тощо; якщо це стосунки 3 іншою людиною, то поцікавтесь, наприклад, чи пообідала вона, чи зручно їй добиратися додому чи до місця вашої зустрічі тощо.

Модуль 2. «Чинники посилення почуття власності: контроль, самоінвестування та інтимне знання".

Метою другого модулю є моделювання ситуацій з посиленням i послабленням рівнів контролю, самоінвестування та інтимного знання й усвідомлення відповідних результатів і наслідків.

Завдання 1. Перевірка домашнього завдання.

Учасники діляться результатами свого домашнього завдання. Що вдалося, що не вдалося, що було легко, а що складно. Чому? Далі ведучий просить оцінити, наскільки посилилося чи послабилося почуття власності щодо цього об'єкта власності після виконання завдань, як змінилися переживання.

У такий спосіб учасники підходять до основної теми модулю.

Завдання 2. Моделювання ситуащій.

Усі учасники об’єднують у чотири мікрогрупи приблизно по п’ять осіб.

Група 1. В межах мікрогрупи один учасник $\epsilon$ «власником» та отримує завдання, 3 гідно 3 яким у нього проявляється посилений контроль над об’єктом власності, самоінвестування та глибоке інтимне знання. Другий учасник («потенційний власник») не знає певної інформації, не докладав зусиль, але хоче отримати об’єкт власності. Учасники не знають завдання один одного.

Група 2. Кілька учасників із групи (2-3) отримують завдання, що вони спільно володіють певним об'єктом власності (наприклад, спільна квартира членів сім'ї). Інші учасники не володіють цим об'єктом, один із них претендує на об'єкт власності, а ще одна особа не претендує і не залучена до стосунків власності. 
Група 3. Усі члени мікрогрупи $є$ співвласниками одного спільного об'єкта власності (наприклад, озеро в місті, поряд з їхнім будинком, де вони всі регулярно прогулюються, відпочивають тощо). Кожен учасник отримує завдання, де вказано, якою мірою він долучався до підтримки стану озера, оскільки вони мають різний рівень почуття власності, контролю, самоінвестування і глибокого знання. Виникає потреба виконати спільні дії щодо об'єкта (наприклад, прибрати біля озера, заселити туди риб тощо).

Група 4. Об'єктом власності є той самий спільний об'єкт, наприклад, міський парк чи озеро. Однак ніхто з учасників ніколи не долучався до підтримування його чистоти.

Учасники в межах своєї групи і відповідно до отриманого завдання мають розіграти ситуацію. Важливо при цьому виявляти свої переживання, прагнути докладати зусиль до захисту чи розвитку об'єкта власності, які відчуття були пережиті та у зв'язку з чим. Після роботи в мікрогрупах, результати презентуються у спільному колі.

Завдання 3. Групова робота «Моє, наше, чуже, нічиє»

Учасники об’єднуються в 4 групи. Кожна група працюватиме над відповідною формою володіння: «моє», «наше», «чуже», «нічиє»

Питання для обговорення в мікрогрупі:

1. Що ви можете назвати словом «моє»/ «наше»/ «чуже»/ «нічиє»?

2. Як ви відчуваєте, розумієте, що це належить тільки вам/ $є$ об'єктом колективного чи спільного володіння/ це не належить вам/ це не належить нікому?

3. Які дії є типовими до такого об'єкта власності?

4. Чи готові ви ділитися, вкладати свої сили, ресурси, захищати, контролювати цей об'єкт власності. I якщо так, то якою мірою?

5. Що станеться, якщо цей об’єкт власності зникне?

Спільне обговорення напрацювань групи в спільному колі.

Підведення підсумків.

Домашнє завдання. Визначити кілька об’єктів власності, що ви можете «моє», «наше», «чуже», «нічиє». Оцініть кожен із цих об'єктів власності за 5-бальною шкалою (1 бал - найнижчий рівень; 5 балів - найвищий рівень) за трьома критеріями: 1) рівень контролю, який ви щодо нього відчуваєте; 2) наскільки ви готові вкладати свій час і ресурси в цей об'єкт власності; 3) наскільки глибокими й 
унікальними є ваші знання про цей об'єкт власності, наскільки часто ви поповнюєте свої знання щодо нього.

Модуль 3. «Наслідки і можливості гармонізацї почуття власності».

Метою третього модулю є формування конструктивних стратегій проживання почуття власності i його гармонізації; визначення можливих причин і наслідків актуалізації чи деактуалізації почуття власності.

Завдання 1. Експеримент «Моя чашка» («Ефект володіння»).

Учасники об'єднуються в дві підгрупи. Обидві групи отримують завдання розробити авторський логотип чашки їхньої фірми чи країни, але одним сказали, що чашки залишаться у співробітників компанії, переважно в тих, хто долучився до розробки макету, а другим - що чашка буде подарована клієнтам компанії чи іноземним гостям.

Після виконання завдання оцінюється за суб'єктивною оцінкою рівень почуття власності щодо розробленого логотипу чашки та рівень готовності віддати цю чашку іншим. Результати порівнюються. Як правило, в групі, де від самого початку знали, що розробляють логотип для інших, проявляється нижчий рівень почуття власності щодо логотипу чашки та нижчий рівень ефекту володіння. Ведучий пояснює суть поняття «ефект володіння» та як він впливає на наші рішення і дії.

Завдання 2. Мозковий штурм «Втрати і наслідки».

Учасники висловлюють свої думки щодо можливих наслідків в результаті втрати об'єкта власності.

Завдання 3. Індивідуальна робота «Мої стратегії щзодо збереження власності».

1. Яким чином ви поводитесь, які дії робите, якщо прагнете отримати певний об'єкт власності?

2. Як ви дієте, якщо відчуваєте загрозу втратити об'єкт власності?

3. За яких умов ваша втрата об'єкта власності буде менш болісною і не такою відчутною?

4. Чи готові ви обміняти чи продати об'єкт власності?

5. Які ваші дії в ситуації втрати об'єкта власності?

Після завершення індивідуальної роботи учасники за бажанням вибірково презентують свої напрацювання на загальне коло. За 
результатами презентації, усі учасники в ході мозкового штурму роблять висновки про загрози втрати власності та можливі наслідки для особи.

Підводячи підсумок, ведучий розповідає про конструктивні стратегії проживання негативних емоцій щодо загрози чи фактичної втрати об'єкта власності.

\section{Завершення і підбиття підсумків}

Завершальний шеринг «Я зрозумів/ла...», «Я отримав/ла...», «Мені забракло...». На цьому етапі також проводиться другий зріз (вихідна діагностика) для визначення ефективності тренінгу.

Обговорення результатів. Запропонована тренінгова програма може бути використана для гармонізації почуття власності особи. Її ефективність було перевірено серед старшокласників та групи студентів, оскільки саме цей період $є$ сенситивним і показовим 3 точки зору сформованості ідентичності, в тому числі ідентичності власника. Далі в онтогенезі розгортаються ситуації актуалізації чи деактулізації почуття власника в тих чи тих практиках. Однак, на нашу думку, ця програма може бути використана для роботи загалом iз дорослими людьми без прив'язки до віку. Також ми вважаємо, що на основі цієї програми може бути розроблена більш вузькоспеціалізована програма саме для роботи 3 гармонізацією почуття власності в конкретній сфері, наприклад щодо робочих завдань чи в процесі формування територіальної громади для підсилення почуття власності до свого регіону тощо. Таку форму групової роботи можна успішно поєднувати 3 індивідуальним консультуванням, доповнюючи роботу більш глибинними техніками.

Установлено, що впровадження цієї програми сприяло підвищенню рівня відповідальності, усвідомлюваності, самоефективності та соціальної активності учасників. Розроблена програма $\epsilon$ ефективною в роботі 3 молоддю 3 метою гармонізації почуття власності і за потреби може бути доповнена та експлікована щодо різних сфер власності серед дорослого населення.

Висновки і перспективи. Почуття власності допомагає людині задовольнити ряд потреб - це і прагнення до контролю й безпеки, i самоідентифікація, і необхідність мати особистий простір. Посилення почуття власності визначає і додатково підвищує цінність об'єкта для його власника. Це зумовлює появу як позитивних, так і негативних переживань особи щодо власності. Як низький рівень сформованості 
почуття власності потребує його підсилення, так i, навпаки, надмірне, загострене відчуття своєї власності може мати деструктивний характер, а отже, потребує гармонізації цього переживання.

Впровадження та вивчення ефективності тренінгової програми гармонізації почуття власності показало доцільність іiі використання серед старшокласників та студентської молоді, а також дорослого населення, що сприяло оптимізації прояву відповідальності, самоефективності, самоідентичності та залученості особи.

Перспективи подальших досліджень вбачаємо в розробці програми психологічного тренінгу для гармонізації почуття власності щодо територіальної громади та власної країни.

\section{Література}

1. Бурменко, Т. Д., Карнышев, А. Д. (2003). Собственность: психологоэкономический анализ. Иркутск: Изд-во БГУЭП.

2. Губеладзе, І. Г. (2020). Соціальні практики володіння як простір реалізації почуття власності. Наукові студї із соціальної та політичної психологї̈, 46 (49), 242-250. DOI: 10.33120/ssj.vi46(49). 173

3. Джеймс, У. (1991). Психология. Москва.

4. Зубіашвілі, I. К. (2018). Тренінгові практики у соціальнопсихологічному забезпеченні монетарної культури старшокласників. Організаційна психологія. Економічна психологія. Соціальна психологія: зб. наук. праць Інституту психологї імені Г. С. Костюка НАПН України, 1, 48, $19-24$.

5. Карамушка, Л. М., Ходакевич, О. Г. (2017). Психологічні особливості ставлення студентської молоді до грошей. Київ: КНЕУ.

6. Нартова-Бочавер, С. К. (2008). Человек суверенный: психологическое исследование субъекта в его бытии. СПб.: Питер.

7. Пайпс, Р. (2008). Собственность и свобода. Москва: Московская школа политических исследований.

8. Хазратова, Н. (2009). Психологічна природа почуття власності. Соиіальна психологія, 5, 103-110.

9. Beaglehole, E. (2015). Property: A Study in Social Psychology. London. Psychology Press.

10. Jussila, I., Tarkiainen, A., Sarstedt, M. \& Hair, J. F. (2015). Individual Psychological Ownership: Concepts, Evidence, and Impications for Research in Marketing. Journal of Marketing Theory and Practice, 23(2), 121-139. DOI: 10.1080/10696679.2015.1002330

11. Kahneman, D., Knetsch, J. L., Thaler, R. H. (1991). Anomalies: The Endowment Effect, Loss Aversion, and Status Quo Bias. Journal of Economic Perspectives, 5(1): 193-206. DOI: 10.1257/jep.5.1.193 
12. Noguti, V. \& Bokeyar, A. L. (2014). Who am I? The relationship between self-concept uncertainty and materialism. International Journal of Psychology, 49(5), 323-333. DOI: 10.1002/ijop.12031

13. Peck, J., \& Shu, S. B. (Eds.). (2018). Psychological Ownership and Consumer Behavior. Springer International Publishing. Retrieved from DOI: https://doi.org/10.1007/978-3-319-77158-8

14. Pierce, J .L., Kostova, T. \& Dirks, K. T. (2002). The state of psychological ownership: Integrating and extending a century of research. Review of General Psychology. 7(1). DOI: 10.1037//108/0-9-2680.7.1.84

15. Poretski, L., Arazy, O., Lanin, J., Nov, O. (2021). Who Owns What? Psychological Ownership in Shared Augmented Reality. International Journal of Human-Computer Studies, 150. DOI: 10.1016/j.ijhcs.2021.102611

16. Preston, S. D., Gelman, S. A. (2020). This land is my land: Psychological ownership increases willingness to protect the natural world more than legal ownership. Journal of Environmental Psychology. 70.101443. DOI:10.1016/j.jenvp.2020.101443

\section{References}

1. Beaglehole, E. (2015). Property: A Study in Social Psychology. London. Psychology Press.

2. Burmenko, T. D., Karnyshev, A. D. (2003). Sobstvennost: PsykholohoEconomicheskiy Analyz [Ownership: Psycho-Economic Analysis]. Irkutsk [in Russian].

3. Hubeladze, I. (2019). Sotsial'ni praktyky volodinnia yak prostir realizatsii pochuttia vlasnosti [Social practices of possession as a space for sense of ownership implementation]. Naukovi studii iz sotsial'noi ta politychnoi psykhologii - Scietific Studios on Social and Political Psychology, 46 (49), 242-250. DOI: 10.33120/ ssj.vi46(49). 173

4. James, W. (1991). Psykholohyya [Psychology]. Moscow [in Russian].

5. Jussila, I., Tarkiainen, A., Sarstedt, M. \& Hair, J. F. (2015). Individual Psychological Ownership: Concepts, Evidence, and Impications for Research in Marketing. Journal of Marketing Theory and Practice, 23(2), 121-139. DOI: 10.1080/10696679.2015.1002330

6. Kahneman, D., Knetsch, J. L. and Thaler, R. H. (1991). Anomalies: The Endowment Effect, Loss Aversion, and Status Quo Bias. Journal of Economic Perspectives, 5(1), 193-206. DOI: 10.1257/jep.5.1.193

7. Karamushka, L. M., \& Khodakevych, O. H. (2017). Psykholohichni osoblyvosti stavlennia studentskoi molodi do hroshei [Psychological features of students' attitude to money]. Kyiv: KNEU [in Ukrainian].

8. Khazratova, N. (2009). Psykholohichna Pryroda Pochuttya Vlasnosti [Psychological Nature of Sense of Ownership]. Sotsialna Psykholohiya - Social Psychology, 5, 103-110 [in Ukrainian]. 
9. Nartova-Bochaver, S. K. (2008). Chelovek Suverennyy: Psykholohycheskoe Issledovaniye Subiekta v Eho Bytii [Man is Sovereign: the Psychological Study of the Subject in His Being]. St. Petersburg: Peter [in Russian].

10. Noguti, V. \& Bokeyar, A. L. (2014). Who am I? The relationship between self-concept uncertainty and materialism. International Journal of Psychology, 49(5), 323-333. DOI: 10.1002/ijop.12031

11. Pipes R. (2008). Sobstvennost i Svoboda [Ownership and Freedom]. Moskva: Moscow School of Political Studies [in Russian].

12. Peck, J., \& Shu, S. B. (Eds.). (2018). Psychological Ownership and Consumer Behavior. Springer International Publishing. Retrieved from DOI: https://doi.org/10.1007/978-3-319-77158-8.

13. Pierce, J. L., Kostova, T. \& Dirks, K. T. (2002). The state of psychological ownership: Integrating and extending a century of research. Review of General Psychology, 7(1). DOI: 10.1037//108/0-9-2680.7.1.84

14. Poretski, L., Arazy, O., Lanin, J., Nov, O. (2021). Who Owns What? Psychological Ownership in Shared Augmented Reality. International Journal of Human-Computer Studies, 150. DOI: 10.1016/j.ijhcs.2021.102611

15. Preston, S. D., Gelman, S. A. (2020). This land is my land: Psychological ownership increases willingness to protect the natural world more than legal ownership. Journal of Environmental Psychology, 70. 101443. DOI:10.1016/j.jenvp.2020.101443

16. Zubiashvili, I. K. (2018). Treninhovi praktyky u sotsialnopsykholohichnomu zabezpechenni monetarnoi kultury starshoklasnykiv [Training practices in social and psychological support for high school students' monetary culture]. Orhanizatsiina psykholohiia. Ekonomichna psykholohiia. Sotsialna psykholohiia: zb. nauk. prats Instytutu psykholohii imeni H. S. Kostiuka NAPN Ukrainy - Organizational psychology. Economic psychology. Social psychology: coll. Science. Proceedings of the GS Institute of Psychology Kostyuk NAPS of Ukraine, 1, 48, 19-24 [in Ukrainian].

Received: 04.05.2021

Accepted: 18.05.2021 